\title{
Effect of diuron on embryo-larval development of Javanese medaka (Oryzias javanicus, Bleeker 1854)
}

\author{
Musa Adamu Ibrahim ${ }^{1,2}$, Syaizwan Zahmir Zulkifli ${ }^{1,3}$, Mohammad Noor Amal Azmai, ${ }^{1,5}$, \\ Ferdaus Mohamat-Yusuff $\mathfrak{3}^{3,4}$, Ahmad Ismail ${ }^{1}$
}

1 Department of Biology, Faculty of Science, Universiti Putra Malaysia, 43400 UPM Serdang, Selangor, Malaysia; moosaad8@gmail.com (M.A.I.); syaizwan@upm.edu.my (S.Z.Z.); mnamal@upm.edu.my (M.N.A.A.); aismail@upm.edu.my (A.I.)

2 Department of Biological Sciences, Faculty of Science, University of Maiduguri, P.M.B. 1069, Maiduguri, Nigeria; moosaad8@gmail.com (M.A.I.)

3 International Institute of Aquaculture and Aquatic Sciences (i-AQUAS), Universiti Putra Malaysia, Batu 7, Jalan Kemang 6, Teluk Kemang 71050 Si Rusa, Port Dickson, Negeri Sembilan, Malaysia; syaizwan@upm.edu.my (S.Z.Z.); ferdius@upm.edu.my (F.M.Y.)

4 Department of Environmental Sciences, Faculty of Environmental Studies, Universiti Putra Malaysia, 43400, UPM Serdang, Selangor, Malaysia; ferdius@upm.edu.my (F.M.Y.)

5 Institute of Bioscience, Universiti Putra Malaysia, 43400 UPM Serdang, Selangor, Malaysia; mnamal@upm.edu.my (M.N.A.A.)

* Correspondence: syaizwan@upm.edu.my; Tel.: +60-13-3975787 (S.Z.Z.)

\begin{abstract}
Some herbicides exert hormetic or biphasic non-monotonic dose-response (NMDR), which is one of the major challenges for ecological risk assessment (ERA) of pesticides pollution. In this study, fish embryo toxicity test (FET) with Javanese medaka (Oryzias javanicus) to sublethal concentration of diuron was determined. Inverted U-shape heart rate was observed at 3 days postexposure (dpe) and 7 dpe. However, at $13 \mathrm{dpe}$ the heart rate (104 \pm 2.90 heartbeat $/ \mathrm{min}$.) decreased in $10.00 \mathrm{mg} . \mathrm{L}^{-1}$ exposed-embryos. At $20 \mathrm{dpe}$, hatchability and survival rate were reduced in 5.00 mg.L-1 and $10.00 \mathrm{mg} . \mathrm{L}^{-1}$ exposed groups. Hormetic developmental deformities were observed in embryo-larvae of Javanese medaka. The results revealed a biphasic effect of low concentrations of diuron on some morphological and physiological features of Javanese medaka embryo-larvae, which might be attributed to endocrine disruption of this herbicide. Further studies to support these effects were recommended.
\end{abstract}

Keywords: hormesis; developmental toxicity; endocrine disruptor; herbicide; ecological risk assessment (ERA)

\section{Introduction}

For some years, pesticides have greatly benefited humans in agriculture and the control of infectious diseases [1]. Diuron is a herbicide for different crops [2]. Diuron, 3-(3,4-Dichlorophenyl)1,1-dimethylurea, which is commonly called Dynex, is also used as an alternative booster biocide that was introduced by the paint industries. Diuron is used in the coating to prevent biofouling of marine organisms on submergible structures of water vessels [3]. Diuron is commonly detected at lower concentrations (ng/L to $\mu \mathrm{g} / \mathrm{L}$ ), but higher concentrations $(\mathrm{mg} / \mathrm{L})$ have been found for example, drainage water from farmlands $[4,5,6]$. Diuron concentration up to $6,742 \mathrm{ng} / \mathrm{L}$ was detected in waters around the UK [7]. It replaces organotin-based paint that was banned because of its deleterious 
effects on non-target species [8]. However, high application and detection of different pesticides in water have resulted in aquatic pollution, which affects the health of non-target organisms [9].

Stock of fish is extremely dependent on environmental factors that are encountered during early development [10]. Diuron was observed to be highly persistent in the marine environment [11]. In teleosts, diuron and its degradation products at $5 \mu \mathrm{g} . \mathrm{L}^{-1}$ and $200 \mu \mathrm{g} . \mathrm{L}^{-1}$ affect morphological, biochemical, physiological and behavioural features of Oreochromis niloticus [12]. It is suspected to be an endocrine disrupting chemical (EDC) and it may likely result in toxic developmental effect [13, 14]. Diuron and some other phenylurea herbicides have exerted in vitro endocrine disrupting effects on neurohypophysis cells [15]. Even though the endocrine disruption ability of this chemical is not clear, there are some indications that diuron has aryl hydrocarbon receptor (AhR)-mediated transactivation effect in vivo and in vitro [16]. As AhR depends on the ligand transcription factor, it controls the genetic factor involved in xenobiotic metabolism, production, and differentiation of cells [16]. More toxicity effects of diuron were observed in phytoplankton as compared to other aquatic organisms [17, 18]. Despite its high application as booster biocides in water vessels, runoff from ureic herbicides used on croplands is the major source of diuron in aquatic ecosystems [19].

Non-monotonic dose-response (NMDR) relation is also known as hormesis or biphasic. Various chemical and physical stressors usually induce it in different experimental systems [20]. Hormesis linked to herbicides was early reported in the 1950s [21]. NMDR describes a pattern with reversal response between low and high doses of a chemical or other substance [22, 23]. A typical biphasic NMDR was observed in some organisms such as prokaryotic organisms, fungi, plants, vertebrates, and invertebrates exposed to pesticides [21, 24]. Some experiments with EDCs showed NMDR relation, with comparatively high frequency to non-EDCs $[25,26]$.

Javanese Medaka (Oryzias javanicus) is distributed all year round in estuaries, freshwater and marine ecosystems in Peninsular Malaysia, Thailand, Singapore, and Indonesia [27]. This fish is one of the excellent aquatic vertebrate-models for in vivo biological research [28]. It is commonly used in numerous studies as a model [29, 30]. Javanese Medaka has all the aspects of 3Rs (reduction, refinement, and replacement) in animal research [31]. Another advantage of using this species as an aquatic animal-model is euryhaline organism [32], and its sensitivity to EDCs and some other toxicants during the early stage of life $[29,30,33]$. A new estuarine model, inland silversides (Menidia beryllina) have also been used both in the laboratory and field research to evaluate endocrine disrupting effects [34, 35].

Embryonic development is an energy-demanding process [36], therefore any process that will interfere with this can cause life-threatening effects. Javanese Medaka has transparent embryo, with small genome size, and transgenic construction [37]. In addition to these conceptual features, there are many technical features such as external development [38]. According to the study knowledge, there is no report on the hormetic non-monotonic dose-response (NMDR) of diuron during the early development of Javanese medaka. Therefore, this study aims to evaluate response of Javanese medaka to sublethal toxicity of diuron, a potential endocrine disrupting chemical (EDC) during the early-life stage.

\section{Materials and Methods}

\subsection{Source of chemicals}

Diuron (1, 1-dimethyl, 3-(3',4'-dichlorophenyl) urea) of analytical grade ( $\geq 98 \%$ purity, CAS: 330 54-1) was purchased from Sigma-Aldrich Co. (St. Louis, MO 63103 USA). Dimethyl sulfoxide (DMSO); 99.9\%, CAS: 67-68-5 was obtained from Friedemann Schmidt Chemical, Kajang, Selangor, Malaysia. 


\subsection{Javanese medaka broodstocks culture and maintenance}

Wild strains of Javanese medaka were obtained from an estuary in Sepang $\left(2^{\circ} 37^{\prime} 15.38^{\prime \prime} \mathrm{N}\right.$, $101^{\circ} 42^{\prime} 38.33^{\prime \prime}$ E), Selangor, Malaysia. They were maintained and cultured to various generations in a recirculating system under suitable conditions (temperature; $26 \pm 1^{\circ} \mathrm{C}, \mathrm{pH} ; 7.8$ - 8.0, DO; $5.4 \mathrm{mg} . \mathrm{L}^{-}$ 1 - 6.0 mg.L-1 , photoperiod; 14:12 h light/dark illumination) [39] for over a year in Javanese Medaka Mass Culture Laboratory, Department of Biology, Universiti Putra Malaysia. The fish were fed ad libitum twice daily with newly hatched ( $<24 \mathrm{~h}$ post-incubation) nauplii of Artemia salina. The culturing of this brine shrimp was based the methods described by Shaala et al. [40]. The system water $(\sim 50 \%)$ was changed and filters were washed twice monthly to reduce the removal of useful microbiota.

\subsection{Preparation of the concentrations and exposure}

Diuron stock concentration (100 mg.L-1) was prepared with the dilution water (artificial brackish water) [38] made with $24 \mathrm{~h}$ aerated 'Instant Ocean ${ }^{\circledR \prime}$ salt solution (21.6 $\pm 0.3 \%$ o environmentally relevant). As reported by OECD [41], two control and five treatment groups were used, namely control (dilution water, solvent ( $0.01 \% \mathrm{v} / \mathrm{v}$ dimethyl sulfoxide; DMSO), $0.60 \mathrm{mg} . \mathrm{L}^{-1}, 1.25 \mathrm{mg}$. $\mathrm{L}^{-1}, 2.50$ mg.L-1 $5.00 \mathrm{mg} . \mathrm{L}^{-1}$, and $10.00 \mathrm{mg} . \mathrm{L}^{-1}$, the highest concentration $\left(10.00 \mathrm{mg} . \mathrm{L}^{-1}\right)$ was selected based on no-observed effect concentration (NOEC) of $96 \mathrm{~h}$ acute toxicity, each group had 3 replicates. Fertilized eggs at $\sim 5 \mathrm{~h}$ post-fertilization (hpf) of stage 8 were collected from $\mathrm{F}_{2}$-parents of the wild strains [42]. Healthy embryos were selected by viewing under a stereomicroscope (Olympus CX31 2D, Japan) to avoid using unfertilized or abnormal egg. The embryos were rinsed with the dilution water, sterilized with $0.3 \%(\mathrm{w} / \mathrm{v})$ and $0.00001 \%(\mathrm{w} / \mathrm{v})$ salt solution (Instant Ocean $\left.{ }^{\circledR}\right)$ and methylene blue, respectively for 2-5 minutes [39], and then transferred into crystallization dishes (100 mL) of various nominal concentrations of diuron. The embryos $(n=30)$ were individually exposed to avoid cross-contamination [43] in a 24-well plate which contained $2.0 \mathrm{~mL}$ of a particular concentration and incubated at $26 \pm 1{ }^{\circ} \mathrm{C}$ on a $14 \mathrm{~h} \mathrm{light:10} \mathrm{h}$ dark photoperiod [40], at light intensity of 837 lux. Newly prepared test concentrations replaced $\sim 90 \%$ of the test concentrations daily [44].

\subsection{Fish embryo toxicity (FET)}

Morphological/physiological endpoints observed were heart rate, hatching rate and survival rate [41, 44]. Heart rate (beats/min.; $\mathrm{n}=8$ ) was counted at 3-day post-exposure ( $3 \mathrm{dpe}$; onset of heartbeat), 7 dpe (structures were clearly observed) and $13 \mathrm{dpe}$ ( $24 \mathrm{~h}$ to first hatching) by using a stopwatch to evaluate the effect on the heartbeat of developing embryo at different concentrations. Proportions of hatched-embryos $(\% ; n=30)$ in the various treatment groups were recorded daily from the day the first hatchling was observed (12 dpe) to the day of termination ( $20 \mathrm{dpe})$. The average survival rate $(\% ; n=30)$ of the groups were recorded daily. The proportion of embryo-larvae $(\% ; \mathrm{n}=30)$ with fully detached tail, coagulated embryo, formed major organs (head, eye, tail, and heart), low pigmentation (melanism), well-developed eyes, somite formed, scoliosis and blood circulation of embryos in different exposed-groups at 10 dpe were determined. Due to the transparency of the embryo, the developmental features were observed and photographed with a camera-mounted Leica ${ }^{\mathrm{TM}}$ microscope (Leica Microsystem, Germany).

\subsection{Ethical statement}

The fishes were sampled, handled and treated according to the methods approved by the Institutional Animal Care and Use Committee, Universiti Putra Malaysia (AUP No.: R006/2016). All experiments were conducted following the mentioned guidelines and regulations.

\subsection{Statistical analysis}


Shapiro-Wilk normality test and one-way ANOVA (parametric) or Kruskal Wallis test (nonparametric) were used. GraphPad Prism 7.0 (GraphPad Software Inc., San Diego, USA) was used to analyze all the data with Dunnett's and Dunn's multiple comparisons tests, respectively at $p<0.05$. Values were presented as mean \pm SEM. Error bar $=$ SEM.

\section{Results}

\subsection{Heart rate}

There was a statistically significant difference in heart rate (heartbeats/min.; HBpM) between the control and treatment groups $(\mathrm{H}(6)=24.47, \mathrm{p}<0.001)$, with mean rank score of $12.83,20.50,16.58$, 37.00, 28.42, 27.25 and 7.92 for control, solvent, $0.6 \mathrm{mg} . \mathrm{L}^{-1}, 1.25 \mathrm{mg} . \mathrm{L}^{-1}, 2.50 \mathrm{mg} . \mathrm{L}^{-1}, 5.00 \mathrm{mg} . \mathrm{L}^{-1}$, and $10.00 \mathrm{mg} . \mathrm{L}^{-1}$ respectively. After $7 \mathrm{dpe}$, a significant difference was observed, $(\mathrm{H}(6)=26.13, \mathrm{p}<0.001)$ at $2.50 \mathrm{mg} . \mathrm{L}^{-1}$, where the heart rate was the highest at $136 \pm 2.53 \mathrm{HBpM}$, as compared to other groups, in which the mean ranking were 18.25 (control), 18.00 (solvent), 16.92 (0.60 mg. $\left.\mathrm{L}^{-1}\right), 32.50$ (1.25 mg.L1), 37.58 (2.50 mg.L-1 $), 20.75$ (5.00 mg.L-1 $)$ and 6.50 (10.00 mg.L-1). A significant decrease in heart rate, $\mathrm{F}(6,35)=15.13, \mathrm{p}<0.001)$ was also observed at 13 dpe as compared to both solvent and control groups, with $104 \pm 2.90 \mathrm{HBpM}$ for $10.0 \mathrm{mg} . \mathrm{L}^{-1}$ treatment group. (Figure 1). The heart rate at $3-7 \mathrm{dpe}$ showed a hormetic-like effect. However, at 13 dpe only the highest $\left(10.00 \mathrm{mg} . \mathrm{L}^{-1}\right)$ was significantly lower than the other groups.

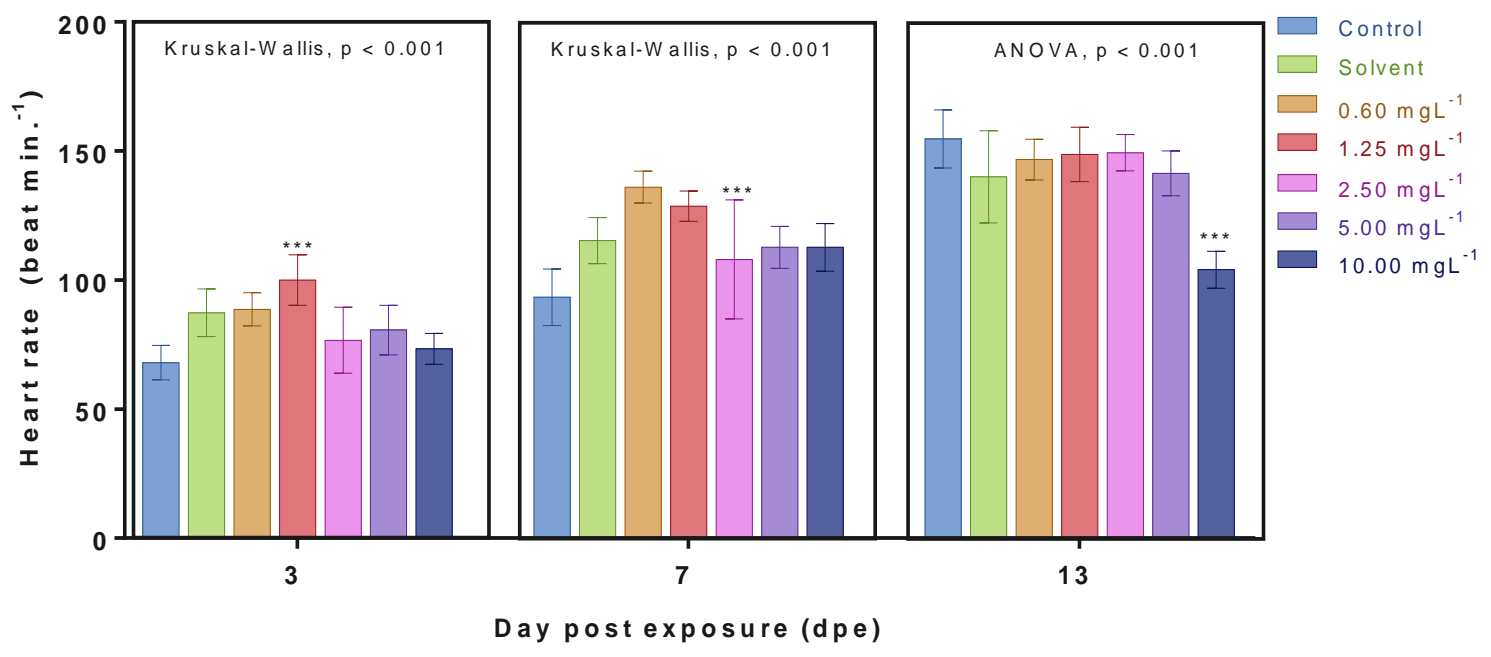

Figure 1. Heart rate $(n=3)$ of Javanese medaka embryo at 3, 7 and 13 dpe to diuron. $* * *=p<0.001$, a significant difference from control. Error bar $=$ SEM.

\subsection{Hatchability}

Hatchability (\%) was significantly different between the control and exposed groups $(\mathrm{H}(6)=$ $19.58, \mathrm{p}<0.003$ ), where the mean ranking score for control, solvent, $0.6 \mathrm{mg} . \mathrm{L}^{-1}, 1.25 \mathrm{mg} . \mathrm{L}^{-1}, 2.50 \mathrm{mg} . \mathrm{L}^{-}$ 1, $5.00 \mathrm{mg} . \mathrm{L}^{-1}$ and $10.00 \mathrm{mg} . \mathrm{L}^{-1}$ were $16.5,19.5,11.0,15.0,8.0,3.5,3.5$, respectively. There was no hatching $(0 \%)$ in the 10.00 mg. $\mathrm{L}^{-1}$ exposed-embryos. Only $3.3 \%$ embryos hatched in the $5.00 \mathrm{mg} . \mathrm{L}^{-1}$ exposed group hatched at the end of the exposure (20 dpe) (Figure 2). 


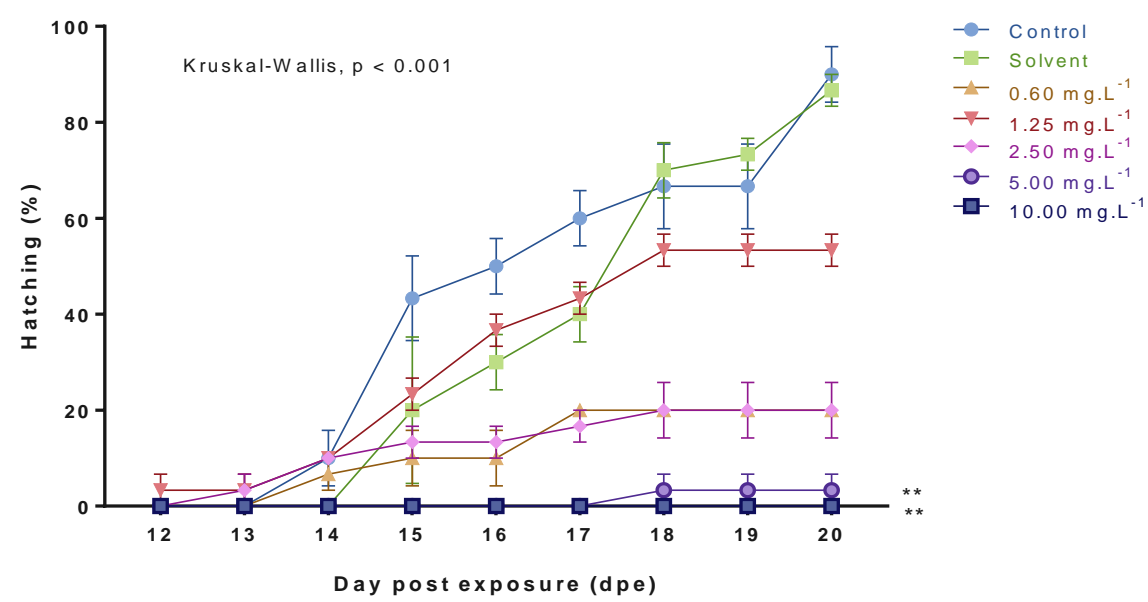

Figure 2. Hatching rate $(n=3)$ of Javanese medaka embryos at 20 days after exposure to sub-lethal concentrations of diuron. ${ }^{* *}=p<0.01$ a significant difference from control. Error bar $=$ SEM.

\subsection{Survival rate}

A significant survival rate $(\%),(\mathrm{H}(6)=16.9, \mathrm{p}<0.003)$ between the treatment groups, with mean rank scores for control (17), solvent (15.17) $0.6 \mathrm{mg} . \mathrm{L}^{-1}$ (4.33), $1.25 \mathrm{mg} . \mathrm{L}^{-1}$ (17), $2.50 \mathrm{mg} . \mathrm{L}^{-1}$ (12.67), 5.00 mg.L $\mathrm{L}^{-1}(5.5)$ and $10.00 \mathrm{mg} . \mathrm{L}^{-1}(5.33)$ (Figure 3$)$ at $20 \mathrm{dpe}$. The similar response pattern at low (0.6 mg.L$\left.{ }^{1}\right)$ and high concentrations (5.00 mg. $\mathrm{L}^{-1}$ and $10.00 \mathrm{mg}$. $\mathrm{L}^{-1)}$ implied non-monotonic effect on the survival rate.

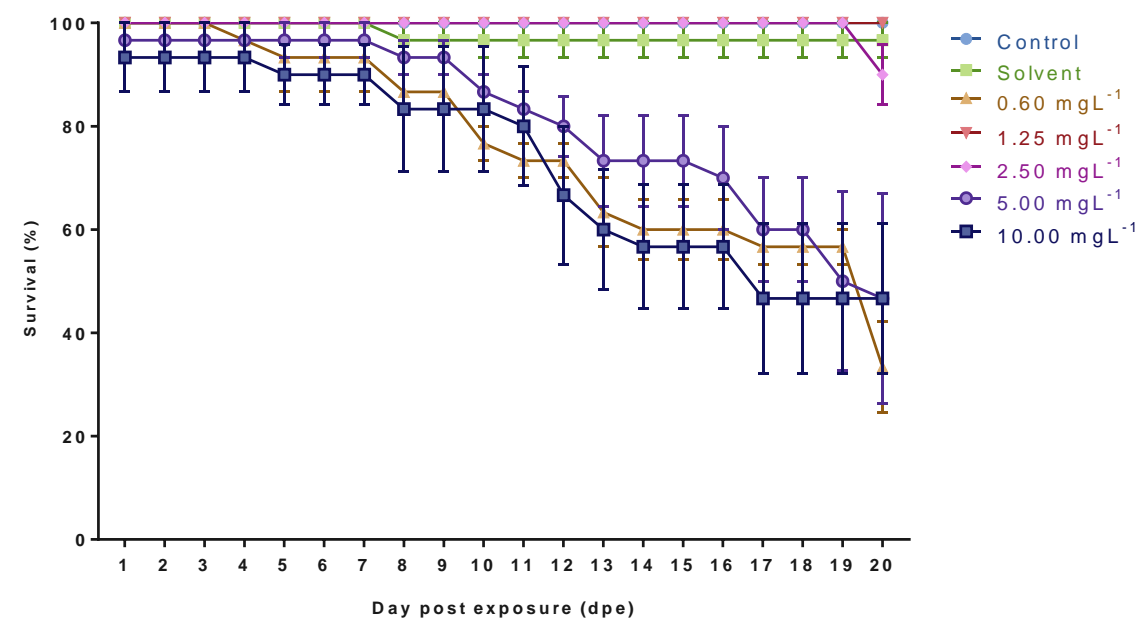

Figure 3. Survival rate $(\mathrm{n}=10)$ of developing embryo-larvae of Javanese medaka at 20 days after exposure to low concentrations of diuron.

\subsection{Diuron in Fish Embryo Acute Toxicity}

The proportion $(\% ; n=30)$ of morphological (fully detached tail, embryo coagulation, formation of major organs (head, eye, tail, and heart) head malformation, pigmentation; melanism, welldeveloped eyes, somite formation, scoliosis) and physiological (blood circulation) features of 
different exposed-groups at 10 dpe. Embryos exposed to $0.6 \mathrm{mg} . \mathrm{L}^{-1}, 5.00 \mathrm{mg} . \mathrm{L}^{-1}$, and $10.00 \mathrm{mg} . \mathrm{L}^{-1}$ had similar response patterns; $3 \%, 3 \%$ and $10 \%$ coagulated, respectively. The major organs formed in 0.6 , $5.00 \mathrm{mg} . \mathrm{L}^{-1}$ and $10.00 \mathrm{mg} . \mathrm{L}^{-1}$-were $40-60 \%$. The low pigmentation (30 - 63\%), fully developed eye $(37 \%-63 \%)$, low somite formation $(23 \%-47 \%)$, scoliosis $(30 \%-47 \%)$ were observed in $0.60 \mathrm{mg} . \mathrm{L}^{-1}$, $5.00 \mathrm{mg} . \mathrm{L}^{-1}$ and $10.00 \mathrm{mg} . \mathrm{L}^{-1}$ exposed-group, respectively (Figure 4). Other morphological characteristics observed in the embryo included yolk-sac oedema, pericardial oedema in the embryolarval development (Figure 5 and Figure 6).

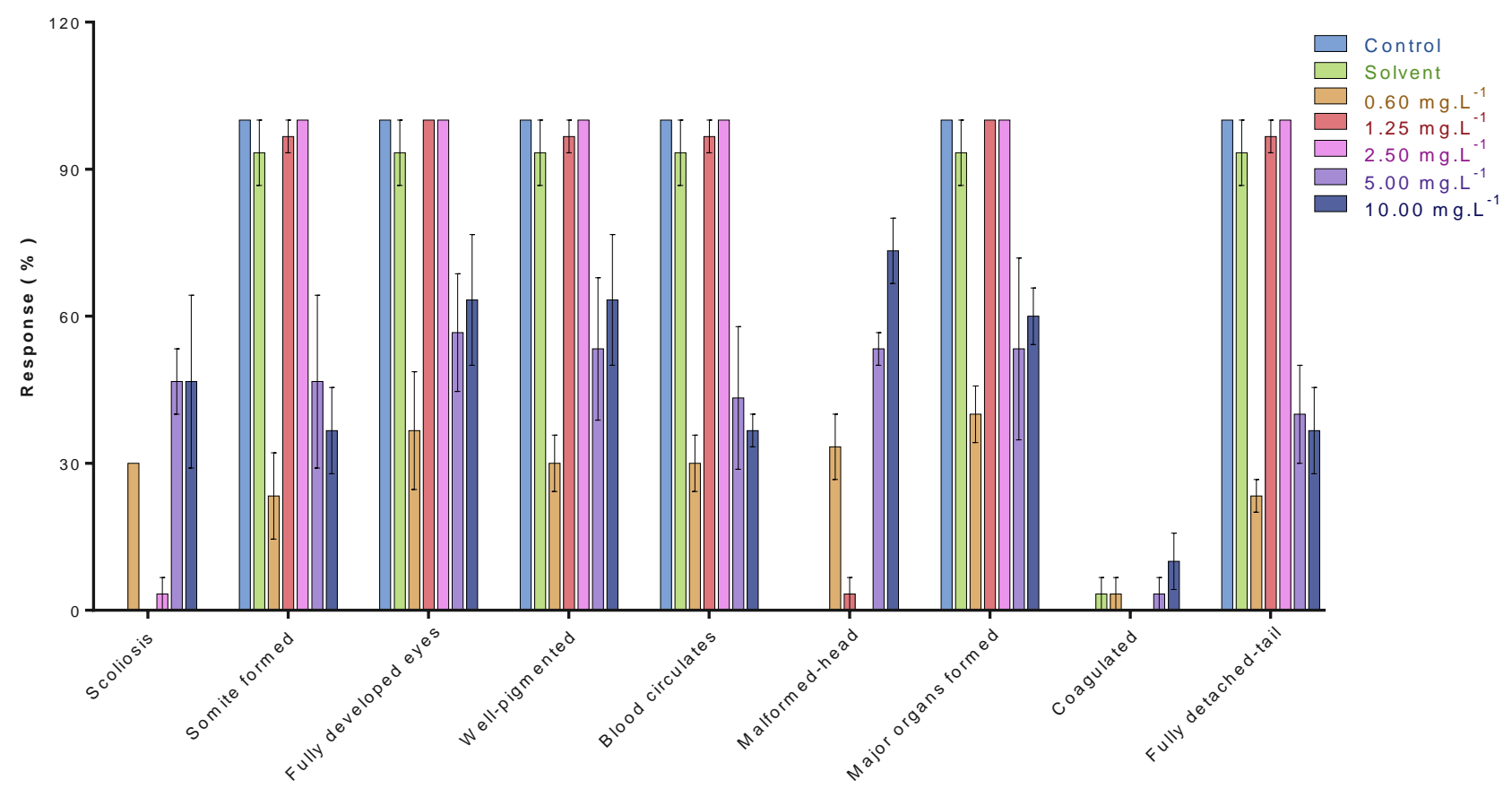

Figure 4. Non-monotonic developmental responses $(n=30)$ of diuron-exposed Javanese medaka embryos after 10 days. $n=30$.
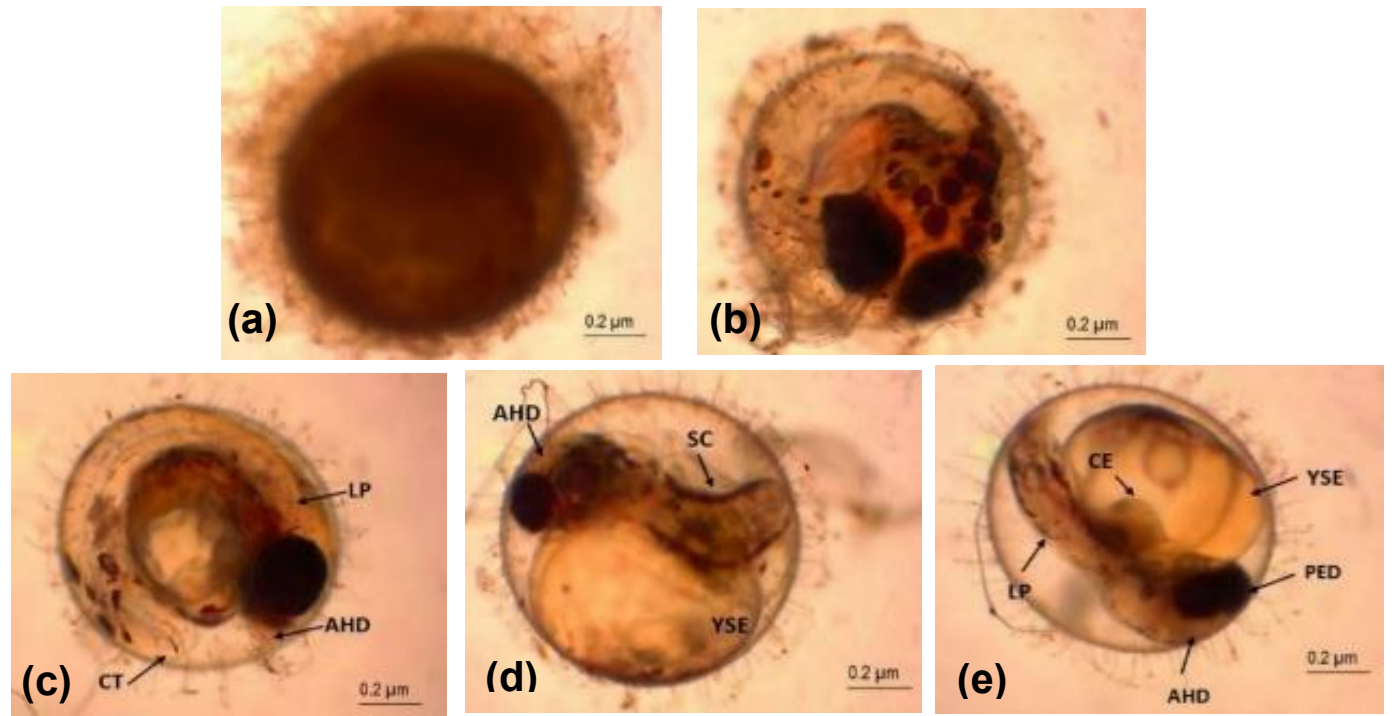

Figure 5. Morphological defects in Javanese medaka embryos (a-e) at 10 dpe exposed to diuron (a) coagulated; $5.0 \mathrm{mg} \cdot \mathrm{L}^{-1}$ (b) normal $\quad$ (c) $0.6 \mathrm{mg} \cdot \mathrm{L}^{-1}$ (d) $5.0 \mathrm{mg} \cdot \mathrm{L}^{-1}$ (e) $10.0 \mathrm{mg} \cdot \mathrm{L}^{-1}$. 
YSE, yolksac oedema; LP, low pigmentation; TC, tail curvature; AHD, abnormal head development; PED, pericardial oedema; SC, scoliosis.
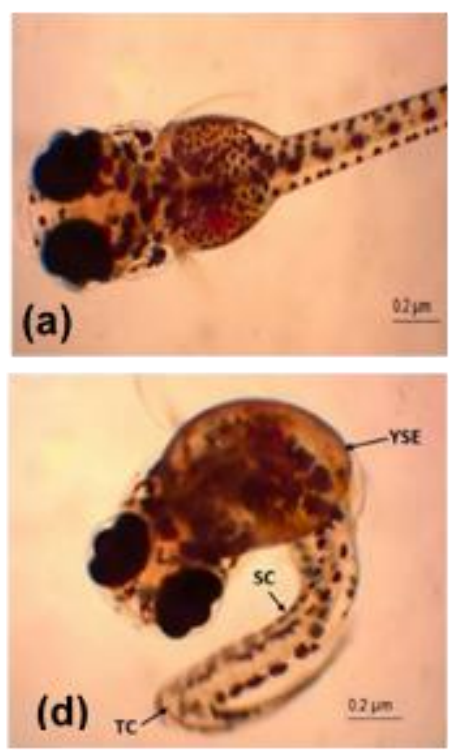
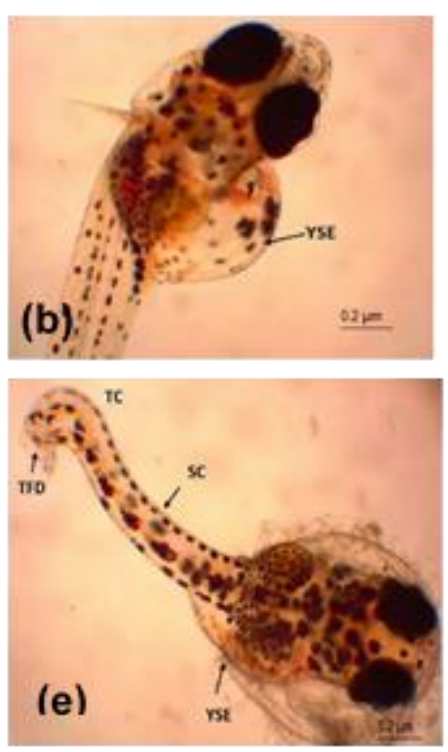
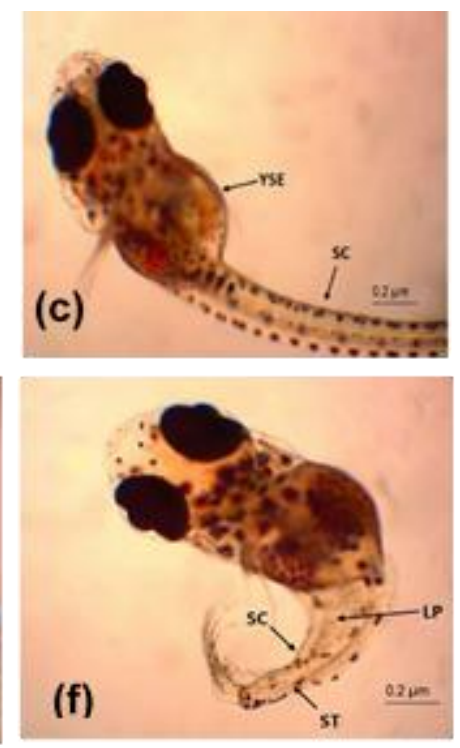

Figure 6. Morphological defects in Javanese medaka fry-sac larvae (a-f) at 2 dph exposed to diuron (a) normal (b and c) $2.5 \mathrm{mg} . \mathrm{L}^{-1}$ (d) $5.0 \mathrm{mg} . \mathrm{L}^{-1}$ (e and f) $0.6 \mathrm{mg} . \mathrm{L}^{-1}$. YSE, yolk-sac oedema; LP, low pigmentation; TC, tail curvature; AHD, abnormal head development; PE, pericardial oedema; SC, scoliosis, CT, coiled tail ST, short tail; TFD, tail fin degradation.

\section{Discussion}

High population growth results in increased food production thereby high demand and application of herbicides, which indirectly ended up in non-target organisms, causing negative biological effects [45]. Direct application of diuron into aquatic ecosystem during the embryonic or early post-embryonic development of fish would pose potential negative effects [46]. In this study, hormetic-like non-monotonic dose-response (NMDR) of diuron, a potential endocrine disruptor, one of the pesticides banned in Europe [47] during the first early development of Javanese medaka (Oryzias javanicus) was revealed based on some endpoints observed. The heart rate, hatchability, survival rate, and developmental deformities in Javanese medaka embryo-larvae exposed to diuron were evaluated. NMDR was reported across multitudinous chemicals including herbicides in some organisms, in the same way, the response was highly different among species which driven researchers to several interpretations of the causes [48,49]. Diuron containing residues in lakes and ponds might result into death of fish and invertebrates that are more sensitive [46].

According to Moreira et al. [35], salinity has affected the levels of thyroid hormone of diuron exposed estuarine fish Menidia beryllina. This indicated that salinity might have played a significant role on hormonal activities of Oryzias javanicus embryos in this study. In the present study, the heart rates at 3 dpe and 7 dpe were in NMDR pattern. However, at 13 dpe, the highest tested concentration (10.00 mg.L $\left.\mathrm{m}^{-1}\right)$, there was a monotonic decrease in heart rate. The heart rate response pattern implied stress exerted by diuron on cardiac activity. The heart rate in this study contradicted the findings of [50], which observed no significant effect between non-exposed (control) group and diuron-exposed zebrafish (Danio rerio) embryos. However, embryo exposed to diuron metabolite (3,4-dichloroaniline) causes low heart rate [51]. The malfunction of the heart rate during the early embryonic stage may result in a lifetime effect as the embryo develops. Li et al. [52] have reported a vital concern on the assessment of cardiac activity during the early developmental stage of Japanese medaka (Oryzias 
latipes). The inverted U-shape in heart rate (i.e. low dose initiation and high dose inhibition) in this study was commonly associated with EDCs which was reported in [53]. Moreira et al. [35] reported a U-shaped effect of diuron on thyroid hormone of an estuarine fish Menidia beryllina. This indicate a potential endocrine disrupting effect of diuron on the physiological development of Javanese medaka embryos as observed in this study.

The hatchability observed at higher sublethal diuron concentrations (5.00 and 10.00 mg.L-1) were monotonic. In the embryo-larval development, the effects of xenobiotics on hatching rate is due to the exertion of toxicity response which disturbs enzymatic pathways in morphological and physiological processes at this vital stage of their life cycle. The delay in the hatching rate of the diuron-exposed embryos in this study was in line with Spencer et al. [54], which reported that exposure of Japanese medaka (Oryzias latipes) to tetrachloroethylene (PCE), a potential EDC delayed hatching. Kao et al. [55] demonstrated that the survival rate and hatching rate of Danio rerio embryos were considerably unaffected after exposure to diuron in comparison to the control group. Call et al. [46]reported that diuron between $2.6-78 \mu \mathrm{g} / \mathrm{L}$ had no significant effect on hatchability and growth of Pimephales promelas embryo at $60 \mathrm{dph}$. However, $78 \mu \mathrm{g} / \mathrm{L}$ at $60 \mathrm{dpe}$ shown a significant increase in mortality or deformities of newly hatched Pimephales promelas larvae at $15.0 \%$ and $2.2 \%$ for exposed and control groups, respectively, similarly the survival rate of the larvae in control group (24.5\%) and exposed group (7.5\%) was significantly reduced [46]. Moreover, Stoss and Haines [56] observed that toluene also an endocrine active chemical had delayed and reduced the hatching rate of Japanese medaka (Oryzias latipes). Furthermore, study by Wisk and Cooper [57] affirmed a concentrationdependent reduction in the hatching rate of 2,3,7,8-tetrachlorodibenzo-p-dioxin (TCDD) exposed Japanese medaka (Oryzias latipes) embryos.

The morphological and physiological deformities observed in this study indicate NMDR of the tested concentrations. The deformities were in line with the early hypotheses which indicated that some of the responses to chemical stressors at low concentration are the basis on which the hormesis was centred [21, 58,59]. This result agrees with the study of Velki et al. [50], which observed that 96h exposure of zebrafish (Danio rerio) embryos to diuron had induced abnormalities during the development such as, pigmentation, head and tail deformities, yolk sac oedema or pericardial oedema and underdevelopment. Kao et al. [55] also reported that Danio rerio embryos exposed to $25 \mathrm{mg} / \mathrm{L}$ diuron showed deformities including spinal curvature, pericardial edema at $48 \mathrm{hpe}$. Schuytema and Nebeker [60] and Moreira et al. [35] reported that diuron induces deformities in embryos and tadpoles of some species of frogs and other aquatic organisms. The extent of the stimulating responses observed for assorted toxic chemicals and species have a range of $30 \%$ and $60 \%$ more than the control [61].

Early life sensitivity is likely due to small size, abnormal morphological and physiological changes, elevated metabolic rate, low energy storage, low migration capabilities and their high dependence on ambient environmental factors $[10,62,63]$.

This result implied a high vulnerability to mortality when the environmental conditions were not favourable as compared to the adult stage $[10,62,63]$. The NMDR characterized by some xenobiotics at low concentrations is one of the major challenges in (eco)toxicological risk assessment of both micro-pollutant and macro-pollutant of environmental concern. Therefore, the standard methods used in establishing safe exposure limits for humans and the environment by extrapolation from high dose testing might not be applicable to NMDR [61, 64, 65]. Studies by Calabrese and Blain [48] and Calabrese and Baldwin [64] observed that more than 9,000 examples of hormetic effects by pesticides, pharmaceuticals, or radiation, and all were independent of dose for a particular substance. Nowadays, NMDR relation is repeatedly observed in experimental research studies as compared to that in the last decade $[26,66,67]$.

There is an increase in reports on research studies that are being precisely designed on the monotonic or NMDR relation for EDCs and other toxicants. Many types of nonlinear, non-monotonic 
responses to EDCs have now been confirmed [68, 69]. The EDCs alter the modes of action in sensitive endocrine tissues, thereby affecting physiological systems, which can also cause exposure-related changes in the normal hormonal regulatory mechanism of negative feedback, hence, may affect the dose-response relation, in the same way, depending on the exposure period. However, EDCs can act through receptor-mediated mechanisms which make them active at very low doses and are usually nonlinear. Moreover, this finding follows the report of Darbre [69]. which indicated that for some EDCs, low dose effect may not be extrapolative of high dose effect, due to difference in mechanism of action at low and high doses [69].

Therefore, NMDR relation is reported regularly, which may affect the ecological risk assessment of some toxic chemicals to non-target organisms. It is also known that irrespective of the mechanism behind NMDR, its occurrence alone defies the traditional method of risk assessment [26, 53]. Environmentally relevant doses of exposure are involved in every aspect of ecological risk assessment (ERA) for environmental monitoring and policymaking. There is an argument on whether low dose NMDR should be considered helpful or destructive for risk assessment [70]. It is important to avoid declining findings just by mismatching the notion of classical toxicology, the Paracelsus' "the dose makes the poison" which implies the dose-dependent response [53, 68, 71, 72, 73].

\section{Conclusions}

Javanese medaka as a model has diverse advantages that would provide more information on toxicity response patterns to EDCs and other emerging environmental pollutants of public and ecosystem health concerns. Most of the endpoints (except hatchability) observed in this study have revealed a biphasic-like NMDR effect of diuron. The endpoint involved; heart rate, hatching rate, survival rate, and structural deformities during the early development stage of Javanese medaka. This study provides more output to the few existing data on exogenous chemical substances with a potential effect on hormonal activities during the early-life stage of fish, and a biphasic response pattern, which is one of the key challenges that hinder ecological risk assessment (ERA) in aquatic pollution monitoring. The authors recommend further studies with this species or different species that will include multi-generation, other biomarkers, gene expression proofiling and aryl hydrocarbon receptor (AhR) mechanisms to support the hormetic-like NMDR and other unknown effects of diuron.

Author Contributions: Conceptualization, S.Z.Z., M.N.A.A., and A.I.; methodology, M.A.I. and S.Z.Z.; software, M.A.I.; validation, S.Z.Z., M.N.A.A., and F.M..; formal analysis, S.Z.Z. and M.A.I..; investigation, S.Z.Z..; resources, S.Z.Z and F.M.; data curation, M.A.I.; writing-original draft preparation, M.A.I.; writing-review and editing, M.A.I., S.Z.Z., M.N.A.A.; visualization, M.A.I., S.Z.Z., M.N.A.A.; supervision, S.Z.Z..; project administration, S.Z.Z and F.M.; funding acquisition, S.Z.Z and F.M. All authors have read and agreed to the published version of the manuscript.

Funding: This research was funded by Universiti Putra Malaysia (UPM) for funding this research under Geran Putra Isiatif Putra Siswazah (GP-IPS) Project No. GP-IPS/2017/9577500, Vot.9577500.

Conflicts of Interest: The authors declare no conflict of interest.

\section{References}

1. Qian, L.; Cui, F.; Yang, Y.; Liu, Y.; Qi, S.; Wang, C. Mechanisms of developmental toxicity in zebrafish embryos (Danio rerio) induced by boscalid. Sci. Total Environ. 2018, 634, 478-487. https://doi.org/10.1016/j.scitotenv.2018.04.012

2. Rubio-Bellido, M.; Morillo, E.; Villaverde, J. Assessment of soil diuron bioavailability to plants and microorganisms through non-exhaustive chemical extractions of the herbicide. Geoderma. 2018, 312, 130138. https://doi.org/10.1016/j.geoderma.2017.09.031

3. Saleh, A.; Molaei, S.; Fumani, N.S.; Abedi, E. Antifouling paint booster biocides (Irgarol 1051 and diuron) in marinas and ports of Bushehr, Persian Gulf. Mar. Pollut. Bull. 2016, 105, 367-372. https://doi.org/10.1016/j.marpolbul.2016.02.037 
4. Vega AB, Frenich AG, Vidal JM. Monitoring of pesticides in agricultural water and soil samples from Andalusia by liquid chromatography coupled to mass spectrometry. Analytica Chimica Acta. 2005, 4;538(12):117-27. https://doi.org/10.1016/j.aca.2005.02.003

5. Tran AT, Hyne RV, Doble P. Determination of commonly used polar herbicides in agricultural drainage waters in Australia by HPLC. Chemosphere. 2007, 67(5):944-53. https://doi.org/10.1016/j.chemosphere.2006.11.002

6. Sørensen SR, Albers CN, Aamand J. Rapid mineralization of the phenylurea herbicide diuron by Variovorax sp. strain SRS16 in pure culture and within a two-member consortium. Appl. Environ. Microbiol.. 2008, 74(8):2332-40. https://doi.org/10.1128/AEM.02687-07

7. Thomas, K.V.; Fileman, T.W.; Readman, J.W. Antifouling paint booster biocides in the UK coastal environment and potential risks of biological effects. Mar. Pollut. Bull. 2001, 42, 677-688. https://doi.org/10.1016/S0025-326X(00)00216-2

8. Hanapiah, M.; Zulkifli, S.Z.; Mustafa, M.; Mohamat-Yusuff, F.; Ismail, A. Isolation, characterization, and identification of potential Diuron-degrading bacteria from surface sediments of Port Klang, Malaysia. Mar. Pollut. Bull. 2018, 127:453-457. https://doi.org/10.1016/j.marpolbul.2017.12.015

9. Dehnert, G.K.; Karasov, W.H.; Wolman, M.A. 2, 4-Dichlorophenoxyacetic acid containing herbicide impairs essential visually guided behaviors of larval fish. Aquat. Toxicol. 2019, 209, 1-12. https://doi.org/10.1016/j.aquatox.2019.01.015

10. Perrichon, P.; Pasparakis, C.; Mager, E.M.; Stieglitz, J.D.; Benetti, D.D.; Grosell, M.; Burggren, W.W. Morphology and cardiac physiology are differentially affected by temperature in developing larvae of the marine fish mahi-mahi (Coryphaena hippurus). Biol. Open. 2017, 6, 800-809. https://doi.org/10.1242/bio.025692

11. Arai, T.; Harino, H.; Ohji, M.; Langston, W.J. Ecotoxicology of antifouling biocides. Springer Japan; 2009, Chp.18 p. 315. https://doi.org/10.1007/978-4-431-85709-9

12. Pereira, T.S.; Boscolo, C.N.; Felício, A.A.; Batlouni, S.R.; Schlenk, D.; de Almeida, E.A. Estrogenic activities of diuron metabolites in female Nile tilapia (Oreochromis niloticus). Chemosphere. 2016, 14, 497-502. https://doi.org/10.1016/j.Chemosphere.2015.12.073

13. Huovinen, M.; Loikkanen, J.; Naarala, J.; Vähäkangas, K. Toxicity of diuron in human cancer cells. Toxicol. in Vitro. 2015, 29, 1577-1586. https://doi.org/10.1016/j.tiv.2015.06.013

14. Kamarudin, N.A.; Zulkifli, S.Z.; Azmai, M.N.A.; Aziz, F.Z.A.; Ismail, A. Herbicide diuron as endocrine disrupting chemicals (EDCs) through histopathalogical analysis in gonads of Javanese medaka (Oryzias javanicus, Bleeker 1854). Animals. 2020, 10, 525. https://doi.org/10.3390/ani10030525

15. Sepp KÖ. Examination of endocrine disruptor effects in neuroendocrine systems, in vivo and in vitro (Doctoral dissertation, szte). 2009.

16. Stejskalova, L.; Dvorak, Z.; Pavek, P. Endogenous and exogenous ligands of aryl hydrocarbon receptor: current state of art. Curr. Drug Metab. 2011, 12, 198-212. https://doi.org/10.2174/138920011795016818

17. Malato, S.; Blanco, J.; Cáceres, J.; Fernández-Alba, A.R.; Agüera, A.; Rodriguez, A. Photocatalytic treatment of water-soluble pesticides by photo-Fenton and TiO2 using solar energy. Catal. Today. 2002, 76, 209-220. https://doi.org/10.1016/S0920-5861(02)00220-1

18. Hakim, M.L.; Nugroho, B,.;Nurrohman, M.N.; Suastika, I.K.; Utama, I.K. Investigation of fuel consumption on an operating ship due to biofouling growth and quality of anti-fouling coating. IOP Conf. Ser.: Earth Environ. Sci. 2019, 339, 012037. https://doi.org/10.1088/1755-1315/339/1/012037

19. Scognamiglio, V.; Antonacci, A.; Patrolecco, L.; Lambreva, M.D.; Litescu, S.C.; Ghuge, S.A.; Rea, G. Analytical tools monitoring endocrine disrupting chemicals. TrAC, Trends Anal. Chem. 2016, 80, 555-567. https://doi.org/10.1016/j.trac.2016.04.014

20. Calabrese, E.J. Hormesis is central to toxicology, pharmacology and risk assessment. Hum. Exp. Toxicol. 2010, 29, 249-261. https://doi.org/10.1177\%2F0960327109363973

21. Brito, I.P.; Tropaldi, L.; Carbonari, C.A.; Velini, E.D. Hormetic effects of glyphosate on plants. Pest. Manage. Sci. 2018, 74, 1064-1070. https://doi.org/10.1002/ps.4523

22. Wang, Z.J.; Liu, S.S.; Qu, R. JSFit: a method for the fitting and prediction of J-and S-shaped concentrationresponse curves. RSC Adv. 2018, 8, 6572-6580. https://doi.org/10.1039/C7RA13220D

23. Agathokleous, E. Environmental hormesis, a fundamental non-monotonic biological phenomenon with implications in ecotoxicology and environmental safety. Ecotoxicol. Environ. Saf. 2018, 148, 1042-53. https://doi.org/10.1016/j.ecoenv.2017.12.003 
24. Calabrese, E.J.; Bachmann, K.A.; Bailer, A.J.; Bolger, P.M.; Borak, J.; Cai, L.; Cedergreen, N.; Cherian, M.G.; Chiueh, C.C.; Clarkson, T.W.; Cook, R.R. Biological stress response terminology: Integrating the concepts of adaptive response and preconditioning stress within a hormetic dose-response framework. Toxicol. Appl. Pharmacol. 2007, 222, 122-128. https://doi.org/10.1016/j.taap.2007.02.015

25. Bergman, Å.; Heindel, J.J.; Jobling, S.; Kidd, K.; Zoeller ,T.R.; World Health Organization. State of the science of endocrine disrupting chemicals 2012. World Health Organization; 2013.

26. Vandenberg, L.N.; Colborn, T.; Hayes, T.B.; Heindel, J.J.; Jacobs, Jr D.R.; Lee, D.H.; Myers, J.P.; Shioda, T.; Soto, A.M.; vom Saal, .FS.; Welshons, W.V. Regulatory decisions on endocrine disrupting chemicals should be based on the principles of endocrinology. Reprod. Toxicol. 2013, 38:1-15. https://doi.org/10.1016/j.reprotox.2013.02.002

27. Yusof, S.; Ismail, A.; Koito, T.; Kinoshita, M.; Inoue, K. Occurrence of two closely related ricefishes, Javanese medaka (Oryzias javanicus) and Indian medaka (O. dancena) at sites with different salinity in Peninsular Malaysia. Environ. Biol. Fishes. 2012, 93, 43-49. https://doi.org/10.1007/s10641-011-9888-x

28. Lin, C.Y.; Chiang, C.Y.; Tsai, H.J. Zebrafish and Medaka: new model organisms for modern biomedical research. J. Biomed. Sci. 2016, 23, 19. https://doi.org/10.1186/s12929-016-0236-5

29. Yusof, S.; Ismail, A.; Alias, M.S. Effect of glyphosate-based herbicide on early life stages of Java medaka (Oryzias javanicus): a potential tropical test fish. Mar. Pollut. Bull. 2014, 85, 494-498. https://doi.org/10.1016/j.marpolbul.2014.03.022

30. Aziz, F.Z.; Zulkifli, S.Z.; Mohamat-Yusuff, F.; Azmai, M.N.; Ismail, A. A histological study on mercuryinduced gonadal impairment in Javanese medaka (Oryzias javanicus). Turk. J. Fish. Aquat. Sci. 2017, 17, 621627. http://doi.org/10.4194/1303-2712-v17_3_18

31. Stoskopf, M.K. Biology and management of laboratory fishes. In Laboratory Animal Medicine. 2015, (pp. 1063-1086). Academic Press. https://doi.org/10.1016/B978-0-12-409527-4.00021-3

32. Inoue, K.; Takei, Y. Diverse adaptability in Oryzias species to high environmental salinity. Zool. Sci. 2002, 19, 727-734. https://doi.org/10.2108/zsj.19.727

33. Mohamat-Yusuff, F.; Sarah-Nabila, A.G.; Zulkifli, S.Z.; Azmai, M.N.; Ibrahim, W.N.; Yusof, S.; Ismail, A. Acute toxicity test of copper pyrithione on Javanese medaka and the behavioural stress symptoms. Mar. Pollut. Bull. 2018, 127, 150-153. https://doi.org/10.1016/j.marpolbul.2017.11.046

34. Brander SM, Jeffries KM, Cole BJ, DeCourten BM, White JW, Hasenbein S, Fangue NA, Connon RE. Transcriptomic changes underlie altered egg protein production and reduced fecundity in an estuarine model fish exposed to bifenthrin. Aquatic Toxicology. 2016, 174:247-60. https://doi.org/10.1016/j.aquatox.2016.02.014

35. Moreira LB, Diamante G, Giroux M, Coffin S, Xu EG, Moledo de Souza Abessa D, Schlenk D. Impacts of salinity and temperature on the thyroidogenic effects of the biocide diuron in Menidia beryllina. Environmental Science \& Technology. 2018, 52(5):3146-55. https://doi.org/10.1021/acs.est.7b04970

36. Rombough, P. The energetics of embryonic growth. Respir. Physiol. Neurobiol. 2011, 178, $22-29$. https://doi.org/10.1016/j.resp.2011.04.026

37. Sari , D.K.; Andriani, I.; Yaqin, K. Histological study of the circulatory system of Sulawesi Medaka fish (Oryzias celebensis) for animal model research. J. Phys. Conf. Ser. 2018, 1028, 012008. https://doi.org/10.1088/1742-6596/1028/1/012008

38. Gallagher, E.P.; Goksøyr, A.; Hahn, M.E.; Larsson, D.G. Fish models in toxicology. Zebrafish. 2007, 4, 9-20. https://doi.org/10.1089/zeb.2006.9998

39. Kinoshita, M.; Murata, K.; Naruse, K.; Tanaka, M. Medaka: Biology, Management, and Experimental Protocols. John Wiley \& Sons; 2009.

40. Shaala, N.M.A.; Zulkifli, S.Z.; Ismail, A.; Azmai, M.N.A.; Mohamat-Yusuf, F. Lethal concentration 50 (LC50) and effects of Diuron on morphology of brine shrimp Artemia salina (Branchiopoda: Anostraca) nauplii. Procedia Environ. Sci. 2015, 30, 279-284. https://doi.org/10.1016/j.proenv.2015.10.050

41. Organization for Economic Corporation and Development (OECD). Guidelines for the Testing of Chemicals: Section 2: Effects on Biotic Systems Test No. 236: Fish Embryo Acute Toxicity (FET) Test. OECD. Paris; 2013.

42. Iwamatsu, T. Stages of normal development in the medaka Oryzias latipes. Mech. Develop. 2004, 121, 605618. https://doi.org/10.1016/j.mod.2004.03.012 
43. Voelker, D.; Vess, C.; Tillmann, M.; Nagel, R.; Otto, G.W.; Geisler, R.; Schirmer, K.; Scholz, S. Differential gene expression as a toxicant-sensitive endpoint in zebrafish embryos and larvae. Aquat. Toxicol. 2007, 81, 355-364. https://doi.org/10.1016/j.aquatox.2006.12.013

44. Cao, F.; Souders, C.L.; Li, P.; Pang, S.; Qiu, L.; Martyniuk, C.J. Developmental toxicity of the triazole fungicide cyproconazole in embryo-larval stages of zebrafish (Danio rerio). Environ. Sci. Pollut. Res. 2019, 26, 4913-4923. https://doi.org/10.1007/s11356-018-3957-z

45. Mukhtar, A.; Mohamat-Yusuff, F.; Zulkifli, S.Z.; Harino, H.; Ismail, A.; Inoue, K. Concentration of organotin and booster biocides in sediments of seagrass area from Sungai Pulai Estuary, south of Johor, Malaysia. Environments. 2019, 6, 26. https://doi.org/10.3390/environments6020026

46. Call, D.J., Brooke, L.T., Kent,R.J., Knuth, M.L., Poirier, S.H., Huot, J.M., Lima, A.R. Bromacil and diuron herbicides: toxicity, uptake, and elimination in freshwater fish. Archives of Environmental Contamination and Toxicology. 1987, 16(5):607-13.

47. Pesce, S.; Margoum, C.; Foulquier, A. Pollution-induced community tolerance for in situ assessment of recovery in river microbial communities following the ban of the herbicide diuron. Agric., Ecosyst. Environ. 2016, 221, 79-86. https://doi.org/10.1016/j.agee.2016.01.009

48. Calabrese, E.J.; Blain, R. The occurrence of hormetic dose responses in the toxicological literature, the hormesis database: an overview. Toxicol. Appl. Pharmacol. 2005, 202, 289-301. https://doi.org/10.1016/j.taap.2004.06.023

49. Calabrese, E.J.; Mattson, M.P. How does hormesis impact biology, toxicology, and medicine? npj Aging Mech. Dis. 2017, 3, 1-8. https://doi.org/10.1038/s41514-017-0013-z

50. Velki ,M.; Di Paolo, C.; Nelles, J.; Seiler, T.B.; Hollert, H. Diuron, and diazinon alter the behavior of zebrafish embryos and larvae in the absence of acute toxicity. Chemosphere. 2017, 180, 65-76. https://doi.org/10.1016/j.chemosphere.2017.04.017

51. Zhu, B.; Liu, T.; Hu, X.; Wang, G. Developmental toxicity of 3, 4-dichloroaniline on rare minnow (Gobiocypris rarus) embryos and larvae. Chemosphere. 2013, 90, 1132-1139. https://doi.org/10.1016/j.chemosphere.2012.09.021

52. Li, K.; Wu, J.Q.; Jiang, L.L.; Shen, L.Z.; Li, J.Y.; He, Z.H.; Wei, P.; Lv, Z.; He, M.F. Developmental toxicity of 2, 4-dichlorophenoxyacetic acid in zebrafish embryos. Chemosphere. 2017, 171, 40-48. https://doi.org/10.1016/j.chemosphere.2016.12.032

53. Lagarde, F.; Beausoleil, C.; Belcher, S.M.; Belzunces, L.P.; Emond, C.; Guerbet, M.; Rousselle, C. Nonmonotonic dose-response relationships and endocrine disruptors: a qualitative method of assessment. Environ. Health. 2015, 14, 13. https://doi.org/10.1186/1476-069X-14-13

54. Spencer, H.B.; Hussein, W.R.; Tchounwou, P.B. Effects of tetrachloroethylene on the viability and development of embryos of the Japanese medaka, Oryzias latipes. Arch. Environ. Contam. Toxicol. 2002, 42, 463-469. https://doi.org/10.1007/s00244-001-0050-1

55. Kao CM, Ou WJ, Lin HD, Eva AW, Wang TL, Chen SC. Toxicity of diuron in HepG2 cells and zebrafish $\begin{array}{llllll}\text { embryos. Ecotoxicology and } & \text { Environmental }\end{array}$ https://doi.org/10.1016/j.ecoenv.2019.01.036

56. Stoss, F.W.; Haines ,T.A. The effects of toluene on embryos and fry of the Japanese medaka Oryzias latipes with a proposal for rapid determination of maximum acceptable toxicant concentration. Environ. Pollut. (1970). 1979, 20, 139-148. https://doi.org/10.1016/0013-9327(79)90066-1

57. Wisk, J.D.; Cooper, K.R. The stage specific toxicity of 2, 3, 7, 8-tetrachlorodibenzo-p-dioxin in embryos of the Japanese medaka (Oryzias latipes). Environ. Toxicol. Chem. 1990, 9, 1159-1169. https://doi.org/10.1002/etc.5620090907

58. Snow, E.T.; Sykora, P.; Durham, T.R.; Klein, C.B. Arsenic, mode of action at biologically plausible low doses: what are the implications for low dose cancer risk?Toxicol. Applied Pharmacol. 2005, 207, 557-564. https://doi.org/10.1016/j.taap.2005.01.048

59. Mukherjee, A.; Sengupta, M.K.; Hossain, M.A.; Ahamed, S.; Das, B.; Nayak, B.; Lodh, D.; Rahman, M.M.; Chakraborti, D. Arsenic contamination in groundwater: a global perspective with emphasis on the Asian scenario. J. Health, Popul. Nutr. 2006, 24, 142-163.

60. Schuytema GS, Nebeker AV. Comparative toxicity of diuron on survival and growth of Pacific treefrog, bullfrog, red-legged frog, and African clawed frog embryos and tadpoles. Arch. Environ. Contam. Toxicol. 1998, 34(4):370-6. 
61. Calabrese, E.J.; Blain, R.B. The hormesis database: the occurrence of hormetic dose responses in the toxicological literature. Regul. Toxicol. Pharm. 2011, 61, 73-81. https://doi.org/10.1016/j.yrtph.2011.06.003

62. Finn, R.N.; Kapoor, B.G. Fish larval physiology. Science Publishers, Inc.; 2008.

63. Rijnsdorp, A.D.; Peck, M.A.; Engelhard, G.H.; Möllmann, C.; Pinnegar, J.K. Resolving the effect of climate change on fish populations. ICES J. Mar. Sci. 2009, 66, 1570-1583. https://doi.org/10.1093/icesjms/fsp056

64. Calabrese, E.J.; Baldwin, L.A. Hormesis: the dose-response revolution. Annu. Rev. Pharmacol. Toxicol. 2003, 43, 175-197. https://doi.org/10.1146/annurev.pharmtox.43.100901.140223

65. Calabrese, E.J.; Bhatia, T.N.; Calabrese, V.; Dhawan, G.; Giordano, J.; Hanekamp, Y.N.; Kapoor, R.; Kozumbo, W.J.; Leak, R.K. Cytotoxicity Models of Huntington's disease and Relevance of Hormetic Mechanisms: A Critical Assessment of Experimental Approaches and Strategies. Pharmacol. Research. 2019, 150, 104371. https://doi.org/10.1016/j.phrs.2019.104371

66. Birnbaum, L.S. Environmental chemicals: evaluating low-dose effects. Envi. Health Persp. 2012, 120, 143-144. https://doi.org/10.1289/ehp.1205179

67. European Food Safety Authority (EFSA). EFSA's 17th Scientific Colloquium on low dose response in toxicology and risk assessment. EFSA Supporting Publications. 2012, 9, 353E.

68. Vandenberg, L.N,.;Colborn, T.; Hayes, T.B.; Heindel, J.J.; Jacobs, Jr D.R.; Lee, D.H.; Shioda, T.; Soto, A.M.; vom Saal, F.S.; Welshons ,W.V.; Zoeller, R.T. Hormones and endocrine-disrupting chemicals: low-dose effects and nonmonotonic dose responses. Endocr. Rev. 2012, 33, 378-455. https://doi.org/10.1210/er.20111050

69. Darbre, P.D. Endocrine disruption and human health. Academic Press; 2015.

70. Luckey, T.D. Radiation hormesis: the good, the bad, and the ugly. Dose-response. 2006, 4, 169-190. https://doi.org/10.2203/dose-response.06-102.Luckey

71. Alker, A.P.; Smith, G.W.; Kim, K. Characterization of Aspergillus sydowii (Thom et Church), a fungal pathogen of Caribbean sea fan corals. Hydrobiologia. 2001, 460, 105-11. https:/doi.org/10.1023/A:1013145524136

72. Rohr, J.R.; Sager, T.; Sesterhenn, T.M.; Palmer, B.D. Exposure, postexposure, and density-mediated effects of atrazine on amphibians: breaking down net effects into their parts. Environ. Health Persp. 2006, 114, 4650. https://doi.org/10.1289/ehp.8405

73. McMahon, T.A.; Boughton, R.K.; Martin, L.B.; Rohr, J.R. Exposure to the herbicide atrazine nonlinearly affects tadpole corticosterone levels. J. Herpetol. 2017, 51, 270-273. https://doi.org/10.1670/16-126 